\title{
Review Article \\ Shedding Light on a New Treatment for Diabetic Wound Healing: A Review on Phototherapy
}

\author{
Nicolette N. Houreld \\ Laser Research Center, Faculty of Health Sciences, University of Johannesburg, P.O. Box 17011, Doornfontein 2028, South Africa \\ Correspondence should be addressed to Nicolette N. Houreld; nhoureld@uj.ac.za
}

Received 28 August 2013; Accepted 9 October 2013; Published 6 January 2014

Academic Editors: A. Schreiber and S. Ulisse

Copyright (C) 2014 Nicolette N. Houreld. This is an open access article distributed under the Creative Commons Attribution License, which permits unrestricted use, distribution, and reproduction in any medium, provided the original work is properly cited.

\begin{abstract}
Impaired wound healing is a common complication associated with diabetes with complex pathophysiological underlying mechanisms and often necessitates amputation. With the advancement in laser technology, irradiation of these wounds with lowintensity laser irradiation (LILI) or phototherapy, has shown a vast improvement in wound healing. At the correct laser parameters, LILI has shown to increase migration, viability, and proliferation of diabetic cells in vitro; there is a stimulatory effect on the mitochondria with a resulting increase in adenosine triphosphate (ATP). In addition, LILI also has an anti-inflammatory and protective effect on these cells. In light of the ever present threat of diabetic foot ulcers, infection, and amputation, new improved therapies and the fortification of wound healing research deserves better prioritization. In this review we look at the complications associated with diabetic wound healing and the effect of laser irradiation both in vitro and in vivo in diabetic wound healing.
\end{abstract}

\section{Introduction}

1.1. Diabetes and Wound Healing. Diabetes Mellitus (DM) is a chronic metabolic disorder due to an absence of, insufficiency in, or resistance to insulin. Complications arise as a result of elevated glucose levels and protein glycation and include cardiovascular disease, retinopathy, nephropathy, angiopathy, and neuropathy. Patients are more likely to have foot problems due to blood vessel and nerve damage and often suffer from sensory loss. Small sores can develop on the feet and often go unnoticed. These later develop into deeper ulcers which become slow to heal, and further complications such as infection arise which often necessitate amputation due to the spread of infection to the underlying tissue and bone. It is estimated that $15-25 \%$ of patients will develop foot ulcers $[1,2]$, of which $6 \%$ of these will require hospitalization to treat these ulcers [3]. Around $15-20 \%$ of these patients will require lower limb amputation [1] and around $50 \%$ of all non traumatic amputations are as a result of DM [4]. To further highlight the seriousness of diabetes associated lower-limb amputations, the 5-year mortality rate following amputation stands at $39-80 \%$ [5].

To control the development of lower-limb ulcers, patients are required to check their feet daily, wear the correct footwear, and regularly visit their health care provider. It is estimated that more than 200 million people worldwide suffer from DM, and in 2004, 3.4 million people died as a result of DM [6]. DM and its associated complications impact heavily on the patient, their family, health care departments, and countries. The treatment of chronic wounds is becoming more of a burden due to the increase in health care costs, an aging population, and an increase in the incidence of diabetes [7].

Despite the huge amount of research into the underlying pathogenesis of impaired diabetic wound healing, there is still no clear answer and it appears to be a net result of microand macrovascular disease [8] and inadequate angiogenesis (Figure 1). Neuropathy and sensory loss have also been recognized as a major cause of prolonged healing in diabetic patients. In addition, advanced glycation end products also contribute to the pathogenesis [8], and hyperglycemia adds to the oxidative stress.

There is a decrease in wound strength, reduced angiogenesis, and poor wound contraction $[8,9]$. In DM, there is a disruption in clot formation and the inflammatory phase is dysregulated $[8,10]$, often with a prolonged and excessive inflammatory response. Hypoxia is associated with diabetic wounds and further amplifies the inflammatory response [11]. 


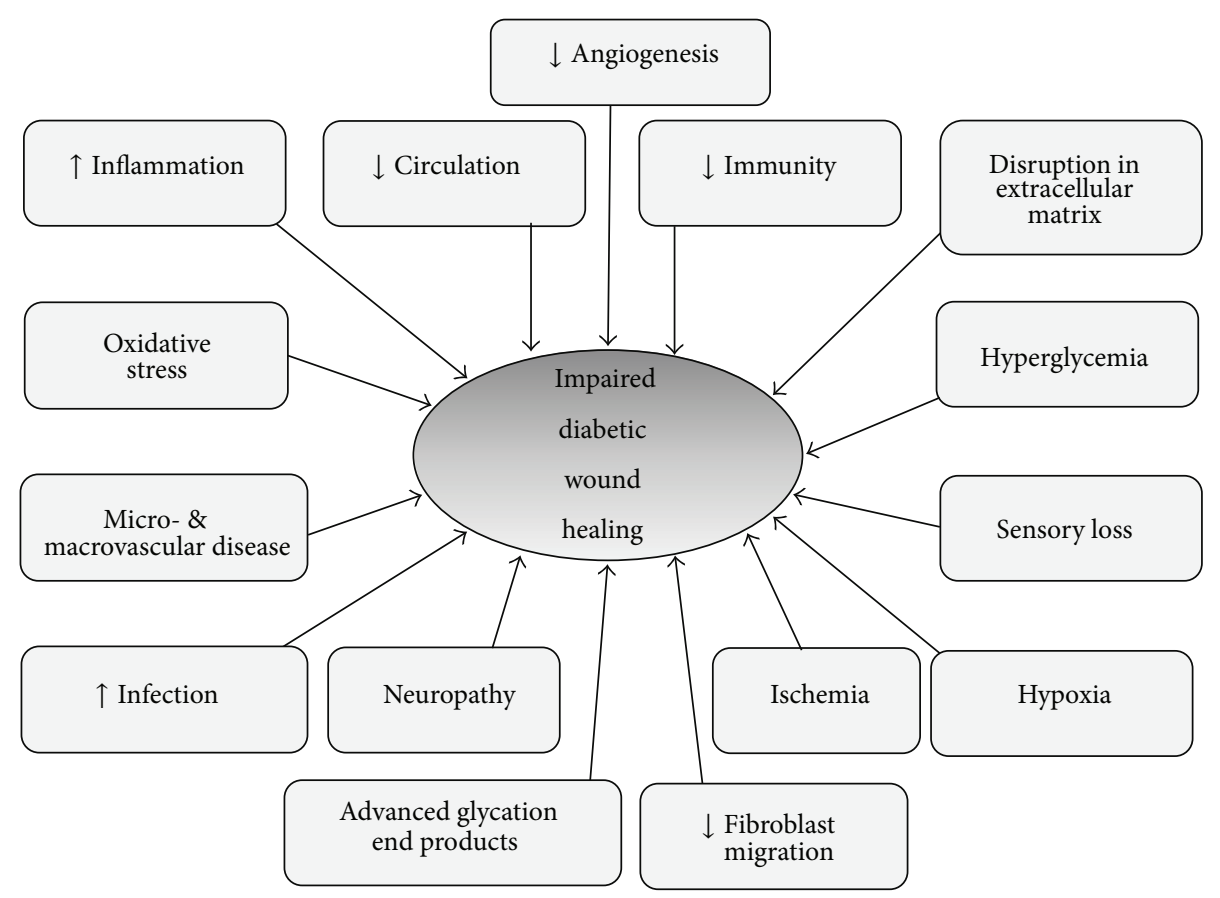

FIGURE 1: Some of the underlying pathogenesis of impaired diabetic wound healing.

Formation of the extracellular matrix (ECM) is a crucial step in wound healing and provides structural integrity to tissue. In diabetic wound healing, there is a malformation of the ECM due to the disruption in ECM-growth factor interactions and impaired migration and proliferation of fibroblasts [9]. Collagen is an important component of the ECM and is synthesized and maintained by a balance between matrix synthesis and degradation. In DM, there is an imbalance between matrix degrading enzymes, matrix metalloproteases (MMPs), their inhibitors, and tissue inhibitor metalloproteinases (TIMPs). The loss of collagen which is associated with diabetes can be due to decreased levels of its synthesis, enhanced metabolism, or a combination of both [12]. Nonhealing diabetic foot wounds display elevated MMP activity, with a 30- to 60-fold increase in MMP-2 and MMP$9[11,13]$. Dysregulated cellular functions also play a part, such as defective $\mathrm{T}$ cell immunity, leukocyte chemotaxis, phagocytosis, and bactericidal capacity [11].

Infection of diabetic ulcers remains a real problem. It can become life threatening and is one of the most common causes of lower-limb amputation and appropriate treatment is essential [14]. Wounds are commonly infected with Pseudomonas aeruginosa and Staphylococcus [11]. Infection can spread from one ulcer to another as the foot has several intercommunicating compartments, and combined with sensory loss patients can continue walking on these infected ulcers further facilitating their spread [1]. Ischemia complicates matters further by reducing defense mechanisms. Administration of antibiotics has its own complications especially with the emergence of antibiotic resistant bacteria, poor arterial supply which affects antibiotic delivery, correct duration of treatment, and toxicity and allergy to patients.
1.2. Treatment of Diabetic Wounds. Management of the diabetic foot is multidisciplinary and can become problematic. Treatment is both local (treating of the diabetic foot) and systemic (glycemic control). Treatment of the diabetic foot is extensive and can encompass mechanical and surgical debridement, management of the wound base, antibiotic therapy to treat infection, revascularization, prophylactic foot surgery, mechanical off-loading, accommodative orthotics, and an alteration of footwear [2, 14]. Hyperbaric oxygen therapy (HBOT), which entails delivering $100 \%$ oxygen at pressures above one atmosphere, increases the amount of oxygen dissolved in the blood and has been used to treat a variety of wounds $[12,15]$. HBOT has been used as an adjunctive treatment for diabetic foot ulcers; however its evidence of efficiency is limited [12]. Kaya and colleagues [16] treated 184 patients with diabetic foot ulcers with HBOT. Sixty-three percent of patients responded to treatment, while $17 \%$ showed no improvement and $21 \%$ underwent amputations. Complications associated with HBOT are not common but can include claustrophobia, ear, sinus, or lung damage, temporary worsening of short sightedness, and oxygen poisoning [12].

A number of clinical applications have been found for lasers in a variety of medical specialities and have been used in dentistry, dermatology, osteology, physiotherapy, acupuncture, surgery, photodynamic cancer therapy, and chiropractic and veterinary science. Lasers have also been used in the treatment of chronic wounds, including diabetic ulcers.

\section{Phototherapy}

Phototherapy, also known as photobiomodulation, low-level laser therapy (LLLT), involves the application of light (often 
laser light of a specific wavelength or a light emitting diode, LED) to stimulate cellular processes.

The effects of phototherapy are chemical and not thermal. Energy which is delivered to cells produces insignificant and minimal temperature changes, typically in the range of 0.1$0.5^{\circ} \mathrm{C}$ [17]. Cellular responses are the result of changes in photoacceptor molecules, or chromophores. Photoacceptors take part in cellular metabolism and are not connected to a light response, such as chlorophyll which is a photoreceptor [18]. Once the photon energy is absorbed, the photoacceptor assumes an electronically excited state [18], which in turn stimulates cellular metabolism $[19,20]$ by activating or deactivating enzymes which alter other macromolecules such as DNA and RNA [21, 22]. The energy which is absorbed by the photoacceptor can be transferred to other molecules causing chemical reactions in the surrounding tissue; this then gives rise to observable effects at a biological level [18, 23]. Photon energy is absorbed by the chromophores and there is an increase in adenosine triphosphate (ATP) [24, 25] and cell membrane permeability, which leads to activation of secondary messengers which in turn activate a cascade of intracellular signals [26]. There is also an increase in mitochondrial membrane potential and proton gradient [25].

The exact mechanisms of action following laser irradiation are not well understood, and a number of theories exist, the most studied and best understood being that of cytochrome-c oxidase (cyt $a / a_{3}$ ), the terminal enzyme in the eukaryotic mitochondrial respiratory chain (complex IV). Cytochrome $\mathrm{c}$ oxidase facilitates the transfer of electrons to molecular oxygen. The end product of this complex is the production of ATP. Cytochrome c oxidase has two heme moieties (heme $a$ and heme $\left.a_{3}\right)$ and two redox-active copper sites $\left(\mathrm{Cu}_{\mathrm{A}}\right.$ and $\mathrm{Cu}_{\mathrm{B}}$ ), and these are the possible absorbing chromophores for visible red and near infrared (NIR) light $[18,27,28]$. When photon energy is absorbed by cytochrome $\mathrm{c}$ oxidase, there is a change in the mitochondrial redox state and/or pumping of protons across the inner mitochondrial membrane [25] and an increase in ATP synthesis. There is also an increase in intracellular calcium $\left(\left[\mathrm{Ca}^{2+}\right] \mathrm{i}\right)$ which stimulates DNA and RNA synthesis [23]. It has been speculated by Karu [27] that photoirradiation may intensify the transfer of electrons within cytochrome $\mathrm{c}$ oxidase by making more electrons available. An increase in the transfer of electrons and protons accelerates oxidative metabolism which ultimately leads to increased ATP [25]. Photoirradiation causes the reduction or oxidation of cytochrome $c$ oxidase and is dependent on the initial redox status of the enzyme at the time of irradiation [28]. Silveira and colleagues [25, 29] showed that LILI produced an increase in mitochondrial complexes I, II, III, and IV, as well as succinate dehydrogenase. Hu and colleagues [30] also found an increase in cytochrome c oxidase activity and concluded there was a cascade of reactions which altered cellular homeostasis. Houreld et al., [31] showed that irradiation of isolated mitochondria resulted in an increase in cytochrome $\mathrm{c}$ oxidase (complex IV) activity. There is also an increase in the concentration of active mitochondria in irradiated cells. Both effects lead to an increase in ATP. The effect of laser irradiation on the mitochondria at a transcriptional level was also investigated, and there is evidence that that there is an upregulation of genes involved in complexes I, IV, and V [32] (Figure 2).

A second possibility is the localized transient heating of the photoacceptor which may cause structural changes and trigger mechanisms such as activation or inhibition of enzymes [28]. Another theory is the release of nitric oxide (NO) from reduced cytochrome c oxidase which reverses the signalling consequences of excessive NO binding [28, 33, 34], as NO in very low concentrations inhibits cytochrome $\mathrm{c}$ oxidase by competing with oxygen $[33,34]$.

2.1. In Vitro Effects of Photoirradiation. A number of studies, on various cell types, have shown positive effects of photoirradiation. Studies have been conducted on stem cells [35-38], keratinocytes [39, 40], mast cells [41, 42], fibroblasts [43-48], smooth muscle cells [49], osteoblasts [50, 51], and schwann cells [52] to name but a few.

Impaired diabetic wound healing has been associated with impaired cellular function, and there is a decrease in cellular migration, proliferation, NO synthesis, growth factors, and collagen synthesis. There is also an increase in proteinases that degrade the extracellular matrix and collagen (MMPs) and cells appear to be stuck in the inflammatory phase of wound healing. The increase in oxidative stress also leads to increased cell death. Laser irradiation in vitro has shown that these cells respond in a favourable fashion, even irradiation of diabetic cells (Table 1). There is an increase in cellular migration $[45,46]$, proliferation $[44,46,53-56]$, viability $[44,46]$, collagen production $[45,49,57-59]$, ATP [31], mitochondria concentration [31], cytochrome c oxidase activity [31], NO [60], growth factors [57, 58, 61, 62], and gene regulation [32]. There is also a decrease in MMPs [49], apoptosis $[46,55,63]$ and proinflammatory cytokines [46].

Irradiation of hypoxic cells has also shown favourable effects, with an increase in ATP and cyclic adenosine monophosphate (cAMP) [64], proliferation [46, 51], viability [46], transforming growth factor- $\beta 1$ (TGF- $\beta 1$ ) [51], intracellular $\mathrm{Ca}^{2+}[64]$ and mitochondrial membrane potential [64], and a decrease in apoptosis and the pro-inflammatory cytokine tumour necrosis factor alpha (TNF- $\alpha$ ) [46]. Irradiation of hypoxic/ischemic cells resulted in reduced ROS, which results in increased angiogenesis [65]. Laser irradiation restores homeostasis of injured and stressed cells, resulting in improved repair and wound healing.

Not all studies have shown positive effects. Pereira et al. [54] and Marques et al. [66] showed that laser irradiation of fibroblast cells had no effect on the synthesis of procollagen. In fact there were ultrastructural changes to the endoplasmic reticulum which may have resulted in a disruption in protein synthesis [54]. Damante et al. [62] demonstrated that irradiation at $660 \mathrm{~nm}$ had no effect on basic fibroblast growth factor (bFGF). Interestingly, irradiation of the same cells at $780 \mathrm{~nm}$ significantly increased bFGF. Hakki and Bozkurt [57] irradiated human gingival fibroblasts by different laser parameters and found no increase in proliferation at each of the parameters used. However, they did find an increase in 


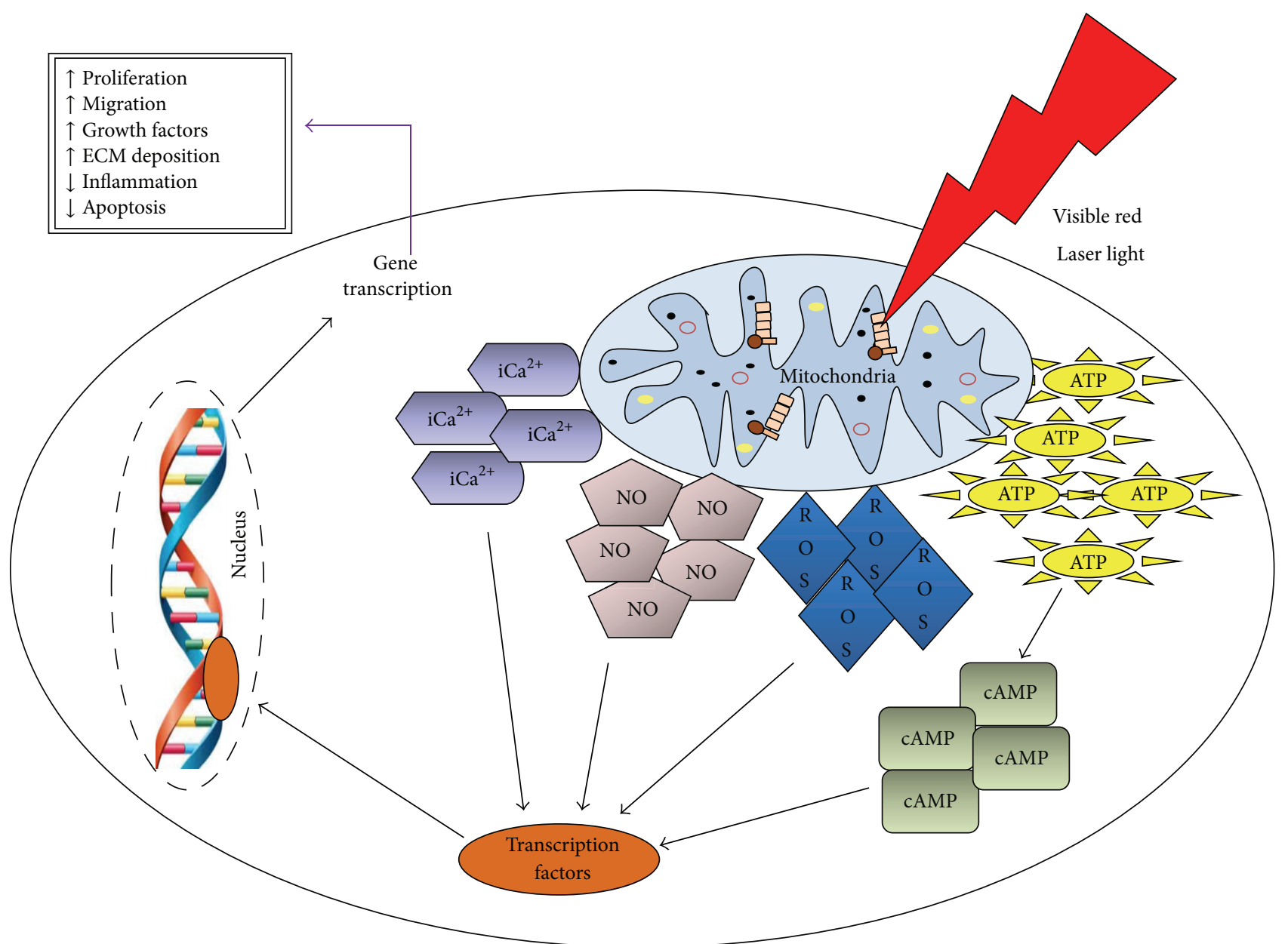

Figure 2: Laser light is absorbed by chromophores in the cell, mitochondria in the case of visible red light. This leads to an increase in adenosine triphosphate (ATP), reactive oxygen species (ROS), nitric oxide (NO), and intracellular calcium (iCa ${ }^{2+}$ ). There is an activation of transcription factors which get translocated to the nucleus and activate gene transcription. This leads to increased cell survival and wound healing.

the transcription of various growth factors, namely, insulinlike growth factor (IGF), vascular endothelial growth factor (VEGF), and transforming growth factor-beta (TGF- $\beta$ ). Irradiation of hypertrophic scar-derived fibroblasts and normal dermal fibroblasts at a wavelength of $880 \mathrm{~nm}$ and a fluence of 2.4 and $4 \mathrm{~J} / \mathrm{cm}^{2}$ had an inhibitory effect [67]. Pereira and colleagues [68] found no benefit when they irradiated human dental pulp stem cells at $660 \mathrm{~nm}$ using various fluencies $(0.05$, $0.30,7$, and $42 \mathrm{~J} / \mathrm{cm}^{2}$ ). Schwartz-Filho and colleagues [69] showed that irradiation at a wavelength of $685 \mathrm{~nm}$ with a density of 25,77 , or $130 \mathrm{~J} / \mathrm{cm}^{2}$ had no effect on osteogenic cell growth or viability.

These adverse effects and difference can be explained by differences in laser parameters. The effects of laser irradiation are highly dependent on the laser parameters such as wavelength, power density, and fluence. Cells respond to LILI in a dose- and wavelength-dependent manner, and the number of exposures as well as the time between exposures plays an important role [47, 70-72]. Higher fluencies have a negative effect on cells, while too low fluences have no effect. The influence of wavelength was demonstrated by
Gupta et al., [73] who demonstrated that irradiation at 635 and $810 \mathrm{~nm}$ had a positive effect on wound healing, while a wavelength of 730 and $980 \mathrm{~nm}$ had no effect. This can be explained by the absorption spectrum of chromophores which absorb light at different wavelengths.

2.2. In Vivo Effects of Photoirradiation. A limited number of clinical studies have been done on diabetic wound healing (Table 1). A reason for the small number of randomized trials may be due to ethical issues associated with doing human clinical trials [67]. A number of studies using phototherapy in animal models have been done (Table 1).

Al-Watban [74] irradiated Sprague-Dawley rats $(n=$ 893 ) to different wavelengths $(532,633,810,980,10,600 \mathrm{~nm}$, and 510-872 nm LED cluster) and fluencies (5, 10, 20, and $30 \mathrm{~J} / \mathrm{cm}^{2}$ ). He showed that phototherapy at a wavelength of $633 \mathrm{~nm}$ accelerated healing and was the best for alleviating diabetic wounds and burn healing. It was suggested that phototherapy with $633 \mathrm{~nm}$ should be given three times a week at a fluence of $4.71 \mathrm{~J} / \mathrm{cm}^{2}$ per dose for the treatment of diabetic burn wounds or $2.35 \mathrm{~J} / \mathrm{cm}^{2}$ 


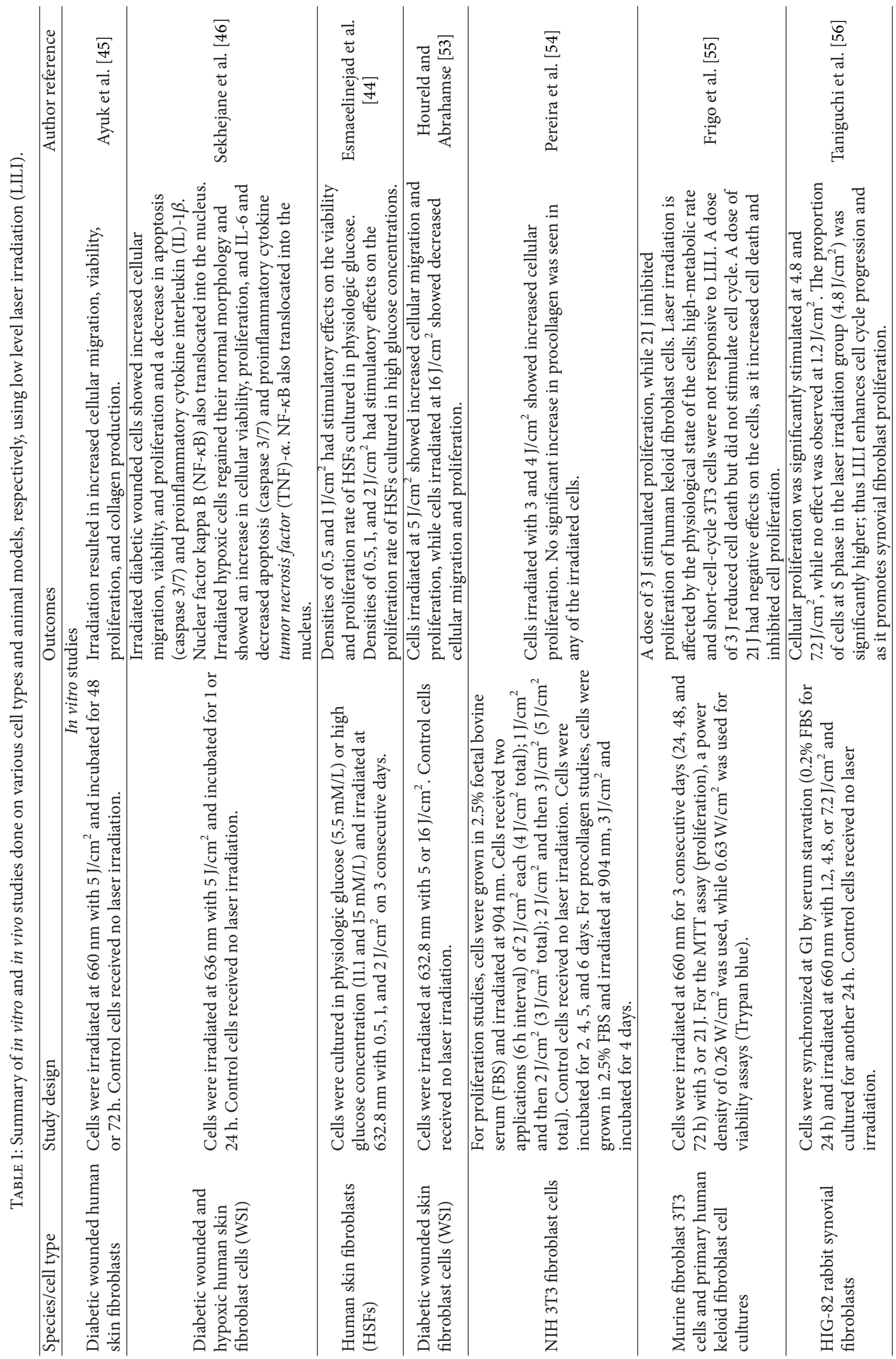




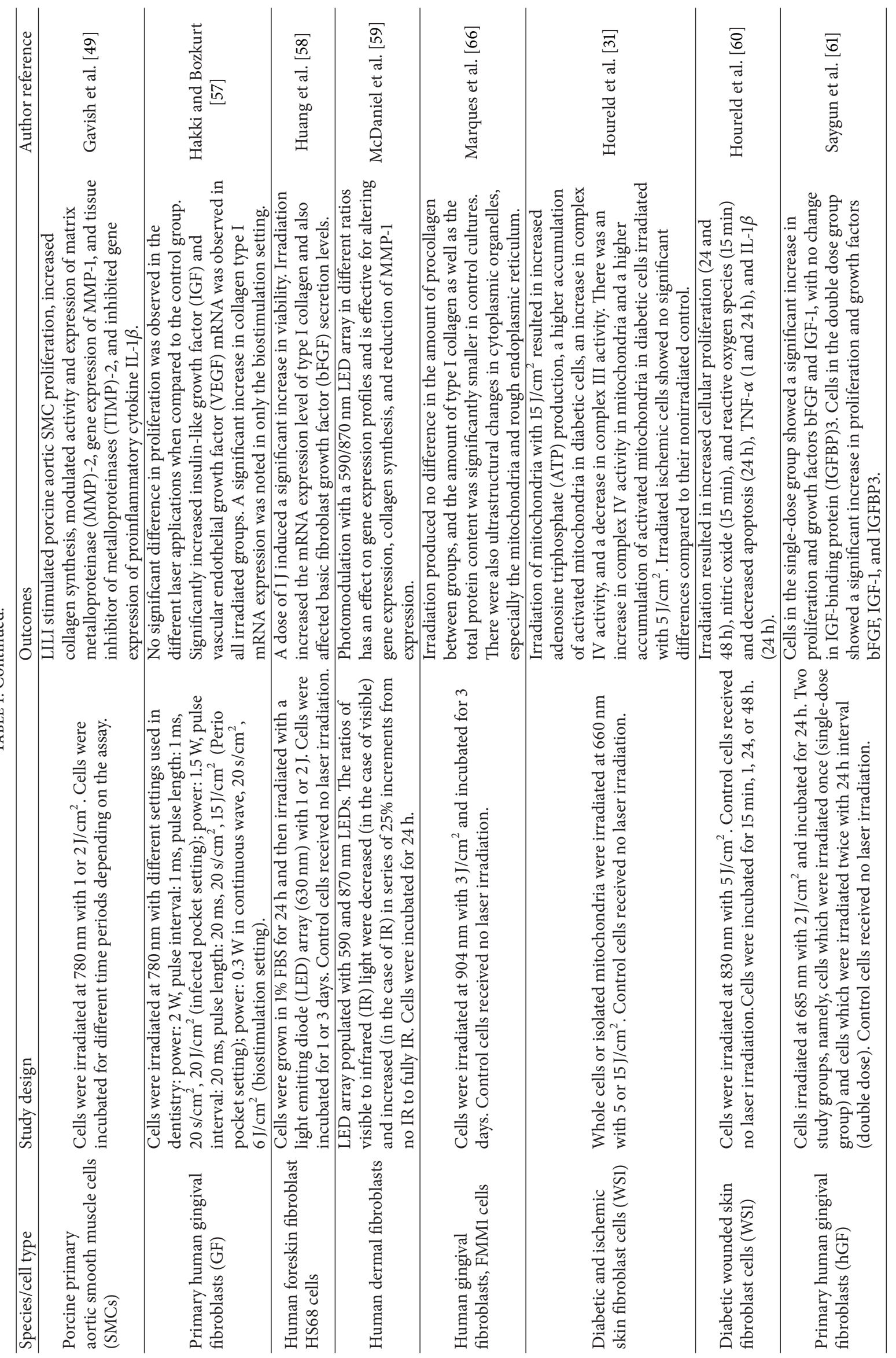


ت्ठ

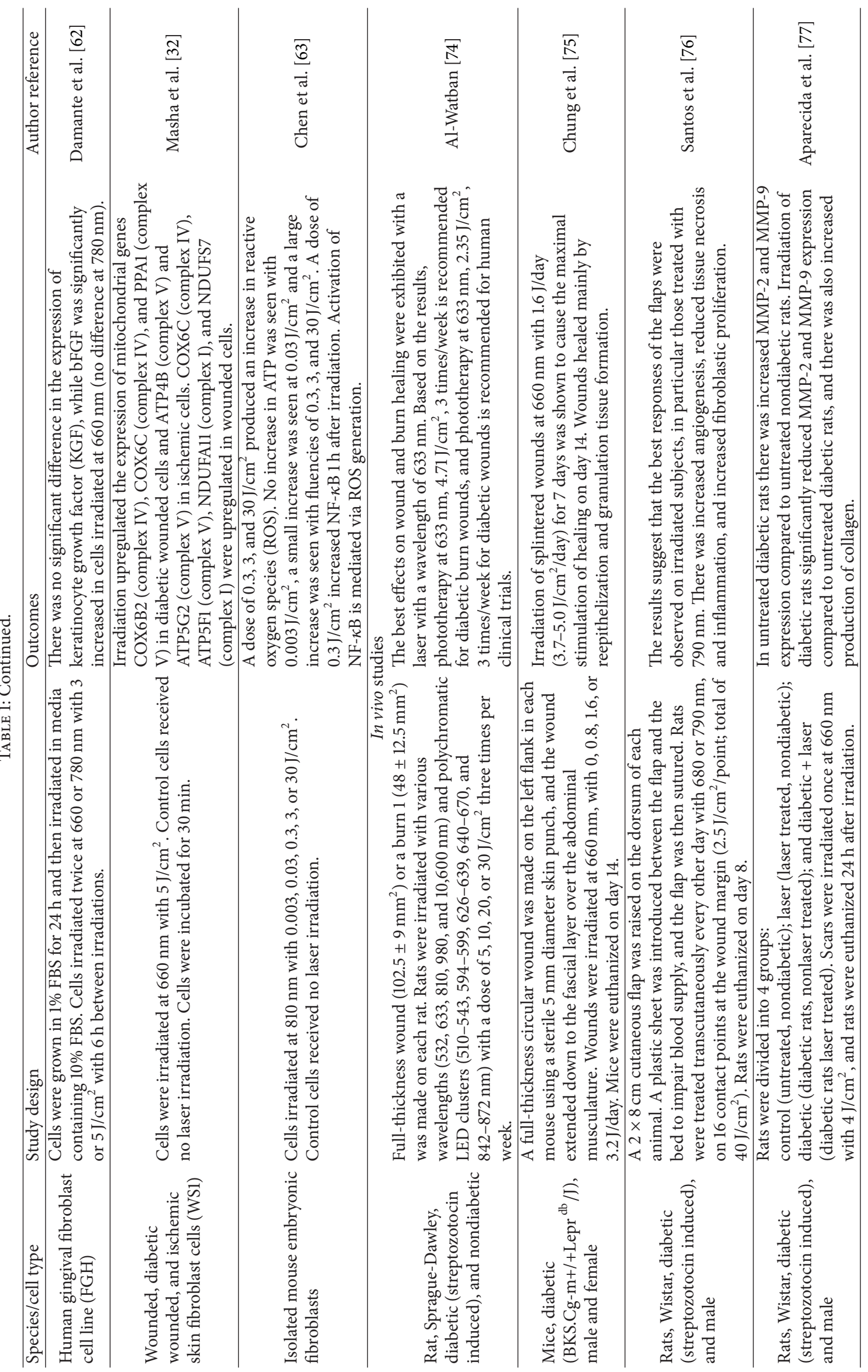




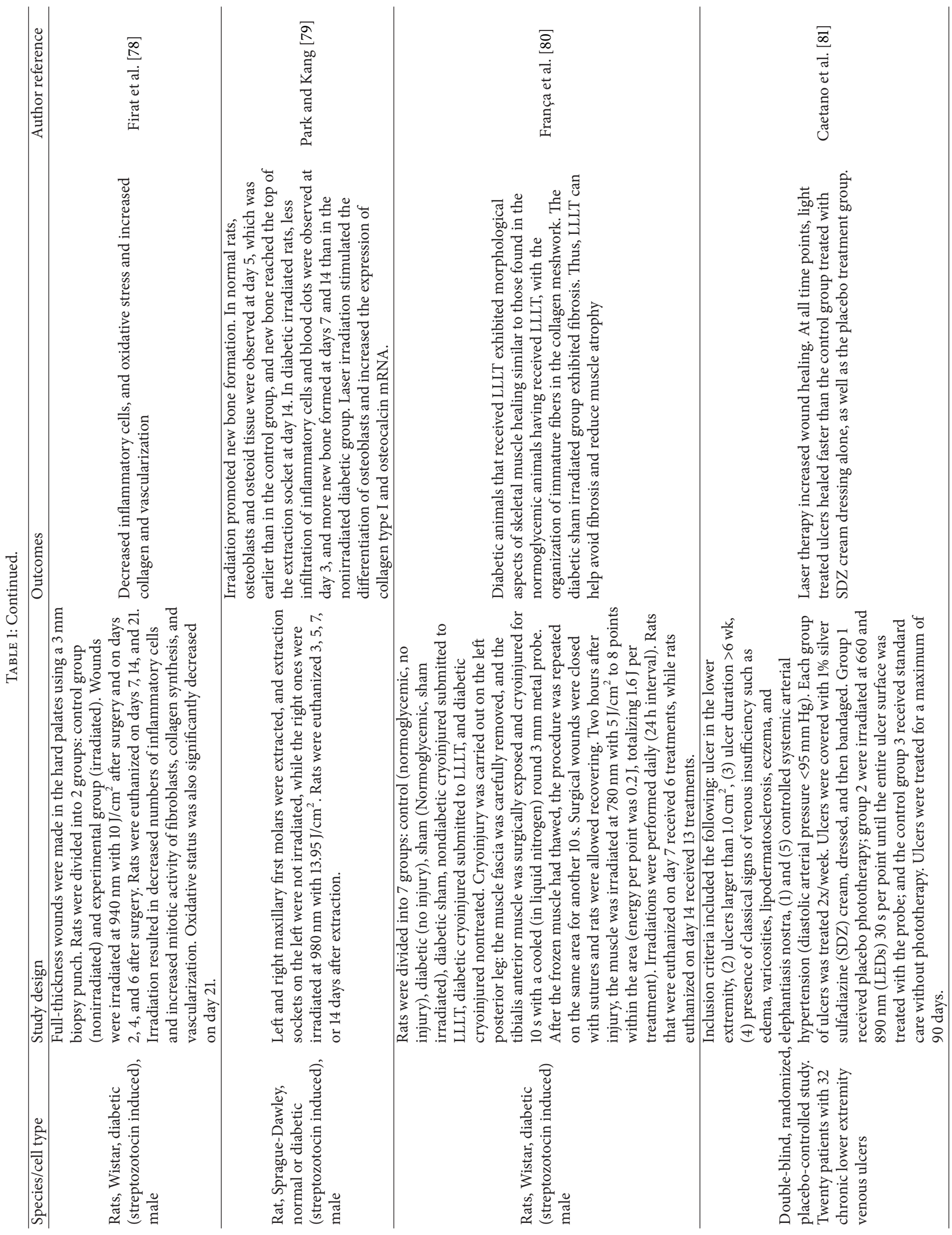




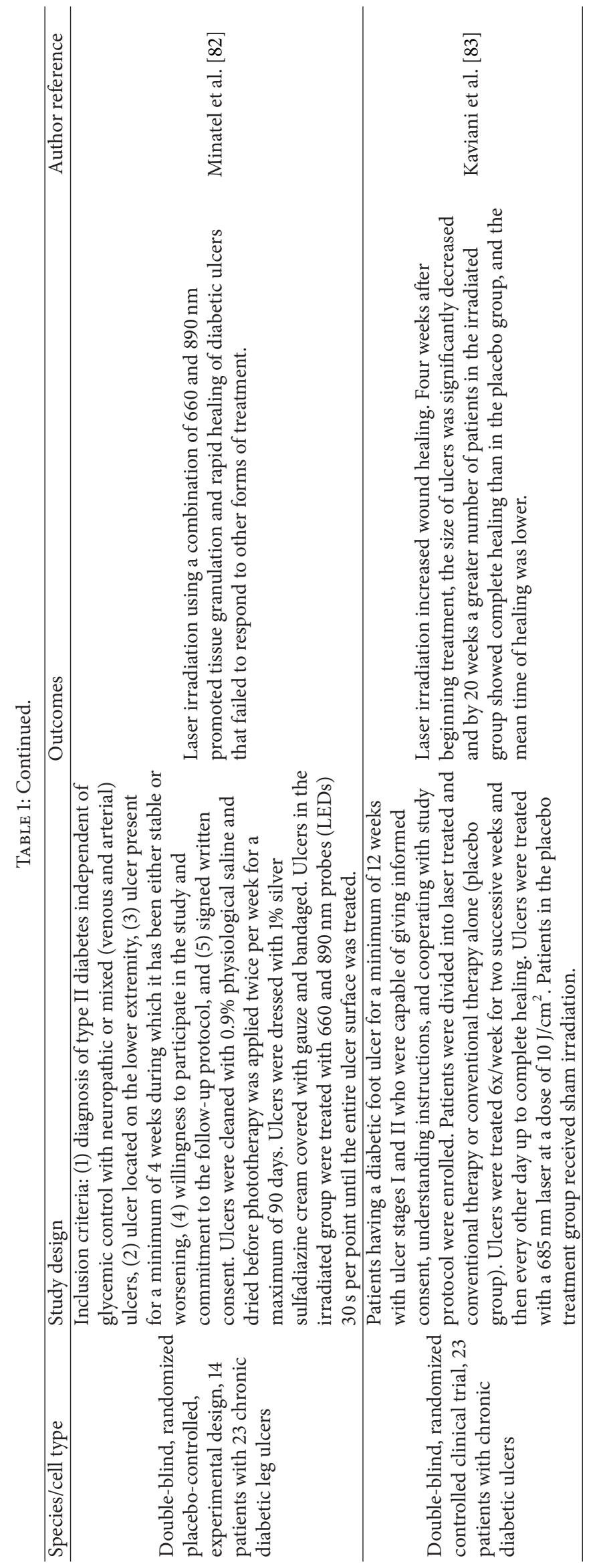


for diabetic wounds. Chung et al. [75] treated full-thickness circular wounds $(5 \mathrm{~mm})$ in diabetic mice (type 2 diabetes) with a $660 \mathrm{~nm}$ laser to various fluencies $\left(0-10 \mathrm{~J} / \mathrm{cm}^{2}\right)$ for seven consecutive days. Wounds were splintered to minimize contraction; the main process of healing would thus be epithelization and granulation. On day 14 mice were euthanized and the wound excised. At a fluence between 3.7 and $10 \mathrm{~J} / \mathrm{cm}^{2}$, splinted irradiated wounds responded better and healed quicker than nonirradiated splintered wounds. Santos et al. [76] irradiated cutaneous flaps with poor circulation in diabetic Wistar rats either with 680 or $790 \mathrm{~nm}\left(2.5 \mathrm{~J} / \mathrm{cm}^{2}\right.$ per point). It was shown that angiogenesis was increased in irradiated rats compared to control, non-irradiated rats, more so when a wavelength of $790 \mathrm{~nm}$ was used.

Irradiation of diabetic male Wistar rats reduced the expression of MMP and accelerated collagen production [77]. Firat and colleagues [78] irradiated full thickness wounds in diabetic male Wistar rats with a $940 \mathrm{~nm}$ diode laser $\left(10 \mathrm{~J} / \mathrm{cm}^{2}\right)$. Histopathological analysis revealed that there was a decrease in inflammatory cells and an increase in collagen and vascularization. Blood tests showed that there was a decrease in oxidative stress. LILI has been found to promote healing in both soft and hard tissue. Irradiation at $980 \mathrm{~nm}$ has been shown to stimulate wound healing and the formation of new bone [79]. Peplow and colleagues [84] demonstrated that the effect of irradiation is due to cellular and biochemical changes in the wound environment, rather than a hypoglycemic effect. One of the long-term complications of diabetes includes musculoskeletal abnormalities, and it is a source of disability in these patients. Laser irradiation $\left(780 \mathrm{~nm}, 5 \mathrm{~J} / \mathrm{cm}^{2}\right)$ of cryoinjured diabetic male Wistar rats showed improved muscle repair, with enhanced reorganization of the myofibers and the perimysium and reduced fibrosis [80].

Caetano et al. [81] conducted a randomized placebocontrolled double-blind study on 20 patients with a total of 32 chronic venous ulcers. Patients were divided into three groups: in group one (placebo), ulcers were cleaned with saline and treated with $1 \%$ silver sulfadiazine (SDZ) cream and patients received a placebo phototherapy; in group two ulcers were treated similarly and patients received phototherapy (combined $660 \mathrm{~nm}$ and $890 \mathrm{~nm}$ at a fluence of $3 \mathrm{~J} / \mathrm{cm}^{2}$ ); and in group three (controls) ulcers were treated similarly and received no phototherapy. Patients that received phototherapy responded to the laser treatment, and ulcers healed significantly faster than the control and placebo group, particularly larger ulcers. Minatel et al. [82] showed that combined irradiation with 660 and $890 \mathrm{~nm}$ promoted granulation and healing of diabetic ulcers that failed to respond to other forms of treatment. Kaviani et al. [83] performed a randomized study on diabetic patients with foot ulcers that would not respond to other treatments. Patients were divided into two groups: group one received conventional treatment and placebo irradiation, while group two received conventional treatment and phototherapy $\left(685 \mathrm{~nm}, 10 \mathrm{~J} / \mathrm{cm}^{2}\right)$. The size of the ulcers in the phototherapy treated group was significantly smaller and the average time of healing was 11 weeks as opposed to 14 weeks as observed in the placebo group.
Infection in diabetic wounds is a major problem, and eradication with antibiotics proves difficult due to decreased blood flow. Laser irradiation has also been shown to inhibit bacteria. Enwemeka et al. [85] showed a dose-dependent decrease in the number of methicillin-resistant Staphylococcus aureus (MRSA) treated in vitro at a wavelength of $470 \mathrm{~nm}$ (blue light). Irradiation at a wavelength of $408 \mathrm{~nm}$ was suggested by Ankri and colleagues [86] in treating infected wounds to clear the infection, followed by irradiation at $730 \mathrm{~nm}$ to speed up the healing process. This is an important breakthrough as combined irradiation with visible red and blue light can potentially be used to treat infected diabetic ulcers.

\section{Conclusion}

DM is the leading cause for lower limb amputations. Current treatments are challenging, lengthy, costly, and associated with failure to heal and relapse. The patient's quality of life is affected, and a burden is placed on both patients and caregivers. There is a need to develop additional therapies to treat diabetic ulcers. Due to its stimulatory effect and no reported sideeffects, laser therapy has been used to treat chronic wounds, including diabetic ulcers. Phototherapy has been shown to be beneficial in treating diabetic ulcers which are unresponsive to conventional treatments. This has led to an improvement in the quality of patient's lives. By studying the effects of LILI in vitro, the underlying mechanisms are being identified. The number of clinical studies in DM is limited, and there is methodological heterogeneity which explains the varied results seen. Better designed, wellcontrolled, randomized, and double-blind studies are needed for this type of therapy to become accepted and used as an adjuvant therapy for the treatment of diabetic ulcers. Phototherapy can be an important tool in speeding up the healing process as well as alleviating pain and inflammation. There is also a need to inform clinicians and other health care providers of the beneficial effects of phototherapy.

\section{Conflict of Interests}

The material in this research paper neither has been published nor is being considered elsewhere for publication.

\section{References}

[1] S. P. Pendsey, "Understanding diabetic foot," International Journal of Diabetes in Developing Countries, vol. 30, no. 2, pp. 75-79, 2010.

[2] N. Singh, D. G. Armstrong, and B. A. Lipsky, "Preventing foot ulcers in patients with diabetes," Journal of the American Medical Association, vol. 293, no. 2, pp. 217-228, 2005.

[3] A. L. Carrington, C. A. Abbott, J. Griffiths et al., "A foot care program for diabetic unilateral lower-limb amputees," Diabetes Care, vol. 24, no. 2, pp. 216-221, 2001.

[4] A. Schindl, M. Schindl, H. Schön, R. Knobler, L. Havelec, and L. Schindl, "Low-intensity laser irradiation improves skin circulation in patients with diabetic microangiopathy," Diabetes Care, vol. 21, no. 4, pp. 580-584, 1998. 
[5] G. E. Reiber, "Epidemiology of foot ulcers and amputations in the diabetic foot," in The Diabetic Foot, J. H. Bowker and M. A. Pfeifer, Eds., pp. 13-32, Mosby, St. Louis, Mo, USA, 2001.

[6] World Health Organisation, "Diabetes, Fact sheet 312," 2011, http://www.who.int/mediacentre/factsheets/fs312/en/.

[7] C. K. Sen, G. M. Gordillo, S. Roy et al., "Human skin wounds: a major and snowballing threat to public health and the economy: perspective article," Wound Repair and Regeneration, vol. 17, no. 6, pp. 763-771, 2009.

[8] M. Peppa, P. Stavroulakis, and S. A. Raptis, "Advanced glycoxidation products and impaired diabetic wound healing," Wound Repair and Regeneration, vol. 17, no. 4, pp. 461-472, 2009.

[9] K. N. Francis-Goforth, A. H. Harken, and J. D. Saba, "Normalization of diabetic wound healing," Surgery, vol. 147, no. 3, pp. 446-449, 2010.

[10] J. Chen, M. Kasper, T. Heck et al., "Tissue factor as a link between wounding and tissue repair," Diabetes, vol. 54, no. 7, pp. 2143-2154, 2005.

[11] S. Guo and L. A. DiPietro, "Critical review in oral biology \& medicine: factors affecting wound healing," Journal of Dental Research, vol. 89, no. 3, pp. 219-229, 2010.

[12] D. O’Reilly, R. Linden, L. Fedorko et al., "A prospective, doubleblind, randomized, controlled clinical trial comparing standard wound care with adjunctive hyperbaric oxygen therapy (HBOT) to standard wound care only for the treatment of chronic, non-healing ulcers of the lower limb in patients with diabetes mellitus: a study protocol," Trials, vol. 12, article 69, 2011.

[13] N. J. Trengove, M. C. Stacey, S. Macauley et al., "Analysis of the acute and chronic wound environments: the role of proteases and their inhibitors," Wound Repair and Regeneration, vol. 7, no. 6, pp. 442-452, 1999.

[14] J. L. Richard, A. Sotto, and J. P. Lavigne, "New insights in diabetic foot infection," Wound Journal of Diabetes, vol. 2, no. 2, pp. 24-32, 2011.

[15] A. M. Eskes, D. T. Ubbink, M. J. Lubbers, C. Lucas, and H. Vermeulen, "Hyperbaric oxygen therapy: solution for difficult to heal acute wounds? Systematic review," World Journal of Surgery, vol. 35, no. 3, pp. 535-542, 2011.

[16] A. Kaya, F. Aydin, T. Altay, L. Karapinar, H. Ozturk, and C. Karakuzu, "Can major amputation rates be decreased in diabetic foot ulcers with hyperbaric oxygen therapy?" International Orthopaedics, vol. 33, no. 2, pp. 441-446, 2009.

[17] A. J. Nemeth, "Lasers and wound healing," Dermatologic Clinics, vol. 11, no. 4, pp. 783-789, 1993.

[18] T. Karu, "Primary and secondary mechanisms of action of visible to near-IR radiation on cells," Journal of Photochemistry and Photobiology B, vol. 49, no. 1, pp. 1-17, 1999.

[19] J. Tuner and L. Hode, Laser Therapy. Clinical Practice and Scientific Background, Prima Books, Grängesberg, Sweden, 2002.

[20] A. L. Barbosa Pinheiro, S. Carneiro Nascimento, A. L. De Barros Vieira et al., "Effects of low-level laser therapy on malignant cells: in vitro study," Journal of Clinical Laser Medicine and Surgery, vol. 20, no. 1, pp. 23-26, 2002.

[21] M. Matić, B. Lazetić, M. Poljacki, V. Duran, and M. Ivkov-Simić, "Low level laser irradiation and its effect on repair processes in the skin," Medicinski Pregled, vol. 56, no. 3-4, pp. 137-141, 2003.

[22] S. Takac and S. Stojanović, "Diagnostic and biostimulating lasers," Medicinski Pregled, vol. 51, no. 5-6, pp. 245-249, 1998.
[23] T. I. Karu, "Primary and secondary mechanisms of the action of monochromatic visible and near infrared radiation on cells," in The Science of Low-Power Laser Therapy, T. I. Karu, Ed., pp. 5383, Gordon and Breach Science, Amsterdam, The Netherlands, 1998.

[24] R. Lubart, H. Friedmann, I. Peled, and N. Grossman, "Light effect on fibroblast proliferaton," Laser Therapy, vol. 5, no. 2, pp. 55-57, 1993.

[25] P. C. L. Silveira, L. A. D. Silva, D. B. Fraga, T. P. Freitas, E. L. Streck, and R. Pinho, "Evaluation of mitochondrial respiratory chain activity in muscle healing by low-level laser therapy," Journal of Photochemistry and Photobiology B, vol. 95, no. 2, pp. 89-92, 2009.

[26] D. H. Evans and H. Abrahamse, "A review of laboratory-based methods to investigate second messengers in low-level laser therapy (LLLT)," Medical Laser Application, vol. 24, no. 3, pp. 201-215, 2009.

[27] T. I. Karu, "Multiple roles of cytochrome c oxidase in mammalian cells under action of red and IR-A radiation," IUBMB Life, vol. 62, no. 8, pp. 607-610, 2010.

[28] T. I. Karu, L. V. Pyatibrat, S. F. Kolyakov, and N. I. Afanasyeva, "Absorption measurements of cell monolayers relevant to mechanisms of laser phototherapy: reduction or oxidation of cytochrome c oxidase under laser radiation at $632.8 \mathrm{~nm}$," Photomedicine and Laser Surgery, vol. 26, no. 6, pp. 593-599, 2008.

[29] P. C. L. Silveira, E. L. Streck, and R. A. Pinho, "Evaluation of mitochondrial respiratory chain activity in wound healing by low-level laser therapy," Journal of Photochemistry and Photobiology B, vol. 86, no. 3, pp. 279-282, 2007.

[30] W.-P. Hu, J.-J. Wang, C.-L. Yu, C.-C. E. Lan, G.-S. Chen, and H.$\mathrm{S}$. Yu, "Helium-neon laser irradiation stimulates cell proliferation through photostimulatory effects in mitochondria," Journal of Investigative Dermatology, vol. 127, no. 8, pp. 2048-2057, 2007.

[31] N. N. Houreld, R. T. Masha, and H. Abrahamse, "Low-intensity laser irradiation at $660 \mathrm{~nm}$ stimulates cytochrome coxidase in stressed fibroblast cells," Lasers in Surgery and Medicine, vol. 44, pp. 429-434, 2012.

[32] R. T. Masha, N. N. Houreld, and H. Abrahamse, "Low-Intensity Laser Irradiation at $660 \mathrm{~nm}$ Stimulates Transcription of Genes Involved in the Electron Transport Chain," Photomedicine and Laser Surgery, vol. 31, no. 2, pp. 47-53, 2013.

[33] T. I. Karu, L. V. Pyatibrat, and N. I. Afanasyeva, "Cellular effects of low power laser therapy can be mediated by nitric oxide," Lasers in Surgery and Medicine, vol. 36, no. 4, pp. 307-314, 2005.

[34] M. G. Mason, P. Nicholls, M. T. Wilson, and C. E. Cooper, "Nitric oxide inhibition of respiration involves both competitive (heme) and noncompetitive (copper) binding to cytochrome c oxidase," Proceedings of the National Academy of Sciences of the United States of America, vol. 103, no. 3, pp. 708-713, 2006.

[35] J.-Y. Wu, C.-H. Chen, C.-Z. Wang, M.-L. Ho, M.-L. Yeh, and Y. -H. Wang, "Low-power laser irradiation suppresses inflammatory response of human adipose-derived stem cells by modulation intracellular cyclic AMP level and NF- $\kappa$ B activity," PLoS ONE, vol. 8, no. 1, Article ID e54067, 2013.

[36] K. Choi, B. J. Kang, H. Kim et al., "Low-level laser therapy promotes the osteogenic potential of adipose-derived mesenchymal stem cells seeded on an acellular dermal matrix," Journal of Biomedical Materials Research Part B, vol. 101, no. 6, pp. 919-928, 2013.

[37] M. Giannelli, F. Chellini, C. Sassoli et al., "Photoactivation of bone marrow mesenchymal stromal cells with diode laser: 
effects and mechanisms of action," Journal of Cellular Physiology, vol. 228, no. 1, pp. 172-181, 2013.

[38] J. A. de Villiers, N. N. Houreld, and H. Abrahamse, "Influence of low intensity laser irradiation on isolated human adipose derived stem cells over 72 hours and their differentiation potential into smooth muscle cells using retinoic acid," Stem Cell Reviews and Reports, vol. 7, no. 4, pp. 869-882, 2011.

[39] F. G. Basso, C. F. Oliveira, C. Kurachi, J. Hebling, and C. A. D. S. Costa, "Biostimulatory effect of low-level laser therapy on keratinocytes in vitro," Lasers in Medical Science, vol. 28, no. 2, pp. 367-374, 2013.

[40] L. Gavish, Y. Asher, Y. Becker, and Y. Kleinman, "Low level laser irradiation stimulates mitochondrial membrane potential and disperses subnuclear promyelocytic leukemia protein," Lasers in Surgery and Medicine, vol. 35, no. 5, pp. 369-376, 2004.

[41] F. F. Fathabadie, M. Bayat, A. Amini, M. Bayat, and F. Rezaie, "Effects of pulsed infra-red low level-laser irradiation on mast cells number and degranulation in open skin wound healing of healthy and streptozotocin-induced diabetic rats," Journal of Cosmetic and Laser Therapy, vol. 15, no. 6, pp. 294-304, 2013.

[42] A. Khoshvaghti, M. Zibamanzarmofrad, and M. Bayat, "Effect of low-level treatment with an $80-\mathrm{Hz}$ pulsed infrared diode laser on mast-cell numbers and degranulation in a rat model of thirddegree burn," Photomedicine and Laser Surgery, vol. 29, no. 9, pp. 597-604, 2011.

[43] F. G. Basso, T. N. Pansani, A. P. Turrioni, V. S. Bagnato, J. Hebling, and C. A. de Souza Costa, "In vitro wound healing improvement by low-level laser therapy application in cultured gingival fibroblasts," International Journal of Dentistry, vol. 2012, Article ID 719452, 6 pages, 2012.

[44] M. Esmaeelinejad, M. Bayat, H. Darbandi, M. Bayat, and N. Mosaffa, "The effects of low-level laser irradiation on cellular viability and proliferation of human skin fibroblasts cultured in high glucose mediums," Lasers in Medical Science. In press.

[45] S. M. Ayuk, N. N. Houreld, and H. Abrahamse, "Collagen production in diabetic wounded fibroblasts in response to lowintensity laser irradiation at $660 \mathrm{~nm}$," Diabetes Technology \& Therapeutics, vol. 14, no. 12, pp. 1110-1117, 2012.

[46] P. R. Sekhejane, N. N. Houreld, and H. Abrahamse, "Irradiation at $636 \mathrm{~nm}$ positively affects diabetic wounded and hypoxic cells in vitro," Photomedicine and Laser Surgery, vol. 29, no. 8, pp. 521530, 2011.

[47] N. Houreld and H. Abrahamse, "In vitro exposure of wounded diabetic fibroblast cells to a helium-neon laser at 5 and $16 \mathrm{~J} / \mathrm{cm}^{2}$ "' Photomedicine and Laser Surgery, vol. 25, no. 2, pp. 78-84, 2007.

[48] I. L. Zungu, D. Hawkins Evans, N. Houreld, and H. Abrahamse, "Biological responses of injured human skin fibroblasts to assess the efficacy of in vitro models for cell stress studies," Alliance Journal of Business Research, vol. 1, no. 4, pp. 060-071, 2007.

[49] L. Gavish, L. Perez, and S. D. Gertz, "Low-level laser irradiation modulates matrix metalloproteinase activity and gene expression in porcine aortic smooth muscle cells," Lasers in Surgery and Medicine, vol. 38, no. 8, pp. 779-786, 2006.

[50] S. Hamajima, K. Hiratsuka, M. Kiyama-Kishikawa et al., "Effect of low-level laser irradiation on osteoglycin gene expression in osteoblasts," Lasers in Medical Science, vol. 18, no. 2, pp. 78-82, 2003.

[51] S.-J. Pyo, W.-W. Song, I.-R. Kim et al., "Low-level laser therapy induces the expressions of BMP-2, osteocalcin, and TGF- $\beta 1$ in hypoxic-cultured human osteoblasts," Lasers in Medical Science, vol. 28 , no. 2, pp. 543-550, 2013.
[52] S. O. Yazdani, A. F. Golestaneh, A. Shafiee, M. Hafizi, H.-A. G. Omrani, and M. Soleimani, "Effects of low level laser therapy on proliferation and neurotrophic factor gene expression of human schwann cells in vitro," Journal of Photochemistry and Photobiology B, vol. 107, no. 1, pp. 9-13, 2012.

[53] N. Houreld and H. Abrahamse, "Irradiation with a $632.8 \mathrm{~nm}$ helium-neon laser with $5 \mathrm{~J} / \mathrm{cm}^{2}$ stimulates proliferation and expression of interleukin-6 in diabetic wounded fibroblast cells," Diabetes Technology and Therapeutics, vol. 9, no. 5, pp. 451-459, 2007.

[54] A. N. Pereira, C. De Paula Eduardo, E. Matson, and M. M. Marques, "Effect of low-power laser irradiation on cell growth and procollagen synthesis of cultured fibroblasts," Lasers in Surgery and Medicine, vol. 31, no. 4, pp. 263-267, 2002.

[55] L. Frigo, G. M. Fávero, H. J. Campos Lima et al., "Lowlevel laser irradiation (InGaAIP-660 nm) increases fibroblast cell proliferation and reduces cell death in a dose-dependent manner," Photomedicine and Laser Surgery, vol. 28, no. 1, pp. S151-S156, 2010.

[56] D. Taniguchi, P. Dai, T. Hojo, Y. Yamaoka, T. Kubo, and T. Takamatsu, "Low-energy laser irradiation promotes synovial fibroblast proliferation by modulating p15 subcellular localization," Lasers in Surgery and Medicine, vol. 41, no. 3, pp. 232-239, 2009.

[57] S. S. Hakki and S. B. Bozkurt, "Effects of different setting of diode laser on the mRNA expression of growth factors and type I collagen of human gingival fibroblasts," Lasers in Medical Science, vol. 27, no. 2, pp. 325-331, 2012.

[58] P.-J. Huang, Y.-C. Huang, M.-F. Su, T.-Y. Yang, J.-R. Huang, and C.-P. Jiang, "In vitro observations on the influence of copper peptide aids for the LED photoirradiation of fibroblast collagen synthesis," Photomedicine and Laser Surgery, vol. 25, no. 3, pp. 183-190, 2007.

[59] D. H. McDaniel, R. A. Weiss, R. G. Geronemus, C. Mazur, S. Wilson, and M. A. Weiss, "Varying ratios of wavelengths in dual wavelength LED photomodulation alters gene expression profiles in human skin fibroblasts," Lasers in Surgery and Medicine, vol. 42, no. 6, pp. 540-545, 2010.

[60] N. N. Houreld, P. R. Sekhejane, and H. Abrahamse, "Irradiation at $830 \mathrm{~nm}$ stimulates nitric oxide production and inhibits proinflammatory cytokines in diabetic wounded fibroblast cells," Lasers in Surgery and Medicine, vol. 42, no. 6, pp. 494-502, 2010.

[61] I. Saygun, S. Karacay, M. Serdar, A. U. Ural, M. Sencimen, and B. Kurtis, "Effects of laser irradiation on the release of basic fibroblast growth factor (bFGF), insulin like growth factor-1 (IGF-1), and receptor of IGF-1 (IGFBP3) from gingival fibroblasts," Lasers in Medical Science, vol. 23, no. 2, pp. 211-215, 2008.

[62] C. A. Damante, G. De Micheli, S. P. H. Miyagi, I. S. Feist, and M. M. Marques, "Effect of laser phototherapy on the release of fibroblast growth factors by human gingival fibroblasts," Lasers in Medical Science, vol. 24, no. 6, pp. 885-891, 2009.

[63] A. C.-H. Chen, P. R. Arany, Y.-Y. Huang et al., "Low-Level laser therapy activates $\mathrm{NF}-\mathrm{kB}$ via generation of reactive oxygen species in mouse embryonic fibroblasts," PLOS ONE, vol. 6, no. 7, Article ID e22453, 2011.

[64] I. L. Zungu, D. Hawkins Evans, and H. Abrahamse, "Mitochondrial responses of normal and injured human skin fibroblasts following low level laser irradiation-an in vitro study," Photochemistry and Photobiology, vol. 85, no. 4, pp. 987-996, 2009.

[65] W. B. Lim, J. S. Kim, Y. J. Ko et al., "Effects of $635 \mathrm{~nm}$ lightemitting diode irradiation on angiogenesis in $\mathrm{CoCl}_{2}$-exposed 
HUVECs," Lasers in Surgery and Medicine, vol. 43, no. 4, pp. 344-352, 2011.

[66] M. M. Marques, A. N. Pereira, N. A. Fujihara, F. N. Nogueira, and C. P. Eduardo, "Effect of low-power laser irradiation on protein synthesis and ultrastructure of human gingival fibroblasts," Lasers in Surgery and Medicine, vol. 34, no. 3, pp. 260-265, 2004.

[67] C. Webb and M. Dyson, “The effect of $880 \mathrm{~nm}$ low level laser energy on human fibroblast cell numbers: a possible role in hypertrophic wound healing," Journal of Photochemistry and Photobiology B, vol. 70, no. 1, pp. 39-44, 2003.

[68] L. O. Pereira, J. P. F. Longo, and R. B. Azevedo, "Laser irradiation did not increase the proliferation or the differentiation of stem cells from normal and inflamed dental pulp," Archives of Oral Biology, vol. 57, no. 8, pp. 1079-1085, 2012.

[69] H. O. Schwartz-Filho, A. C. Reimer, C. Marcantonio, E. Marcantonio Jr., and R. A. C. Marcantonio, "Effects of low-level laser therapy $(685 \mathrm{~nm})$ at different doses in osteogenic cell cultures," Lasers in Medical Science, vol. 26, no. 4, pp. 539-543, 2011.

[70] N. N. Houreld and H. Abrahamse, "Effectiveness of heliumneon laser irradiation on viability and cytotoxicity of diabeticwounded fibroblast cells," Photomedicine and Laser Surgery, vol. 25, no. 6, pp. 474-481, 2007.

[71] D. Hawkins and H. Abrahamse, "Effect of multiple exposures of low-level laser therapy on the cellular responses of wounded human skin fibroblasts," Photomedicine and Laser Surgery, vol. 24, no. 6, pp. 705-714, 2006.

[72] D. H. Hawkins and H. Abrahamse, "The role of laser fluence in cell viability, proliferation, and membrane integrity of wounded human skin fibroblasts following Helium-Neon laser irradiation," Lasers in Surgery and Medicine, vol. 38, no. 1, pp. 74-83, 2006.

[73] A. Gupta, T. Dai, and M. R. Hamblin, "Effect of red and nearinfrared wavelengths on low-level laser (light) therapy-induced healing in partial-thickness dermal abrasion in mice," Lasers in Medical Science. In press.

[74] F. A. H. Al-Watban, "Laser therapy converts diabetic wound healing to normal healing," Photomedicine and Laser Surgery, vol. 27, no. 1, pp. 127-135, 2009.

[75] T.-Y. Chung, P. V. Peplow, and G. D. Baxter, "Laser photobiostimulation of wound healing: defining a dose response for splinted wounds in diabetic mice," Lasers in Surgery and Medicine, vol. 42, no. 9, pp. 656-664, 2010.

[76] N. R. S. Santos, J. N. Dos Santos, J. A. Dos Reis et al., "Influence of the use of laser phototherapy ( $\lambda 660$ or $790 \mathrm{~nm})$ on the survival of cutaneous flaps on diabetic rats," Photomedicine and Laser Surgery, vol. 28, no. 4, pp. 483-488, 2010.

[77] A. Aparecida Da Silva, E. C. Leal-Junior, A. C. Alves et al., "Wound-healing effects of low-level laser therapy in diabetic rats involve the modulation of MMP-2 and MMP-9 and the reduction of collagen types I and III," Journal of Cosmetic and Laser Therapy, vol. 15, no. 4, pp. 210-216, 2013.

[78] E. T. Firat, A. Dağ, A. Günay et al., "The effects of low-level laser therapy on palatal mucoperiosteal wound healing and oxidative stress status in experimental diabetic rats," Photomedicine and Laser Surgery, vol. 31, no. 7, pp. 315-321, 2013.

[79] J. J. Park and K. L. Kang, "Effect of 908-nm GaAIAs diode laser irradiation on healing of extraction sockets in streptozotocininduced diabetic rats, a pilot study," Lasers in Medical Science, vol. 27, pp. 223-230, 2012.
[80] C. M. França, C. de Loura Santana, C. B. Takahashi et al., "Effect of laser therapy on skeletal muscle repair process in diabetic rats," Lasers in Medical Science, vol. 28, no. 5, pp. 1331-1338, 2013.

[81] K. S. Caetano, M. A. C. Frade, D. G. Minatel, L. Á. Santana, and C. S. Enwemeka, "Phototherapy improves healing of chronic venous ulcers," Photomedicine and Laser Surgery, vol. 27, no. 1, pp. 111-118, 2009.

[82] D. G. Minatel, M. A. C. Frade, S. C. França, and C. S. Enwemeka, "Phototherapy promotes healing of chronic diabetic leg ulcers that failed to respond to other therapies," Lasers in Surgery and Medicine, vol. 41, no. 6, pp. 433-441, 2009.

[83] A. Kaviani, G. E. Djavid, L. Ataie-Fashtami et al., "A randomized clinical trial on the effect of low-level laser therapy on chronic diabetic foot wound healing: a preliminary report," Photomedicine and Laser Surgery, vol. 29, no. 2, pp. 109-114, 2011.

[84] P. V. Peplow, T.-Y. Chung, and G. D. Baxter, "Laser photostimulation $(660 \mathrm{~nm})$ of wound healing in diabetic mice is not brought about by ameliorating diabetes," Lasers in Surgery and Medicine, vol. 44, no. 1, pp. 26-29, 2012.

[85] C. S. Enwemeka, D. Williams, S. K. Enwemeka, S. Hollosi, and D. Yens, "Blue 470-nm light kills Methicillin-Resistant Staphylococcus aureus (MRSA) in vitro," Photomedicine and Laser Surgery, vol. 27, no. 2, pp. 221-226, 2009.

[86] R. Ankri, R. Lubart, and H. Taitelbaum, "Estimation of the optimal wavelengths for laser-induced wound healing," Lasers in Surgery and Medicine, vol. 42, no. 8, pp. 760-764, 2010. 


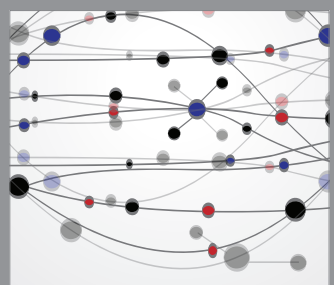

The Scientific World Journal
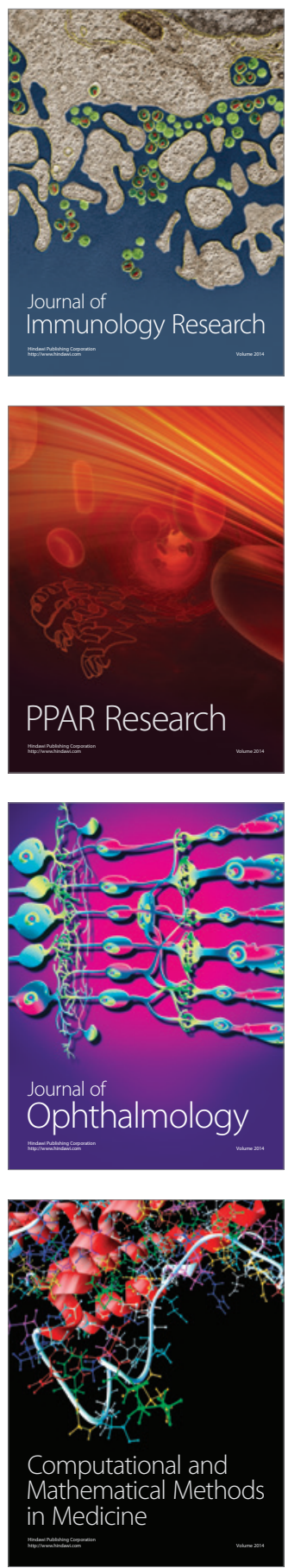

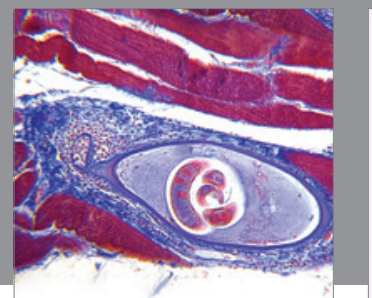

Gastroenterology

Research and Practice
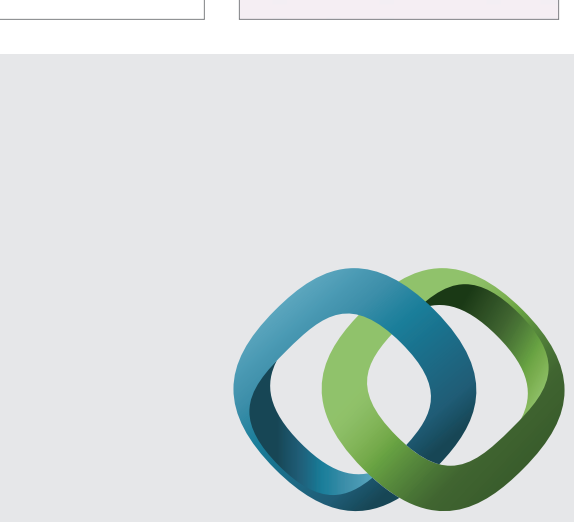

\section{Hindawi}

Submit your manuscripts at

http://www.hindawi.com
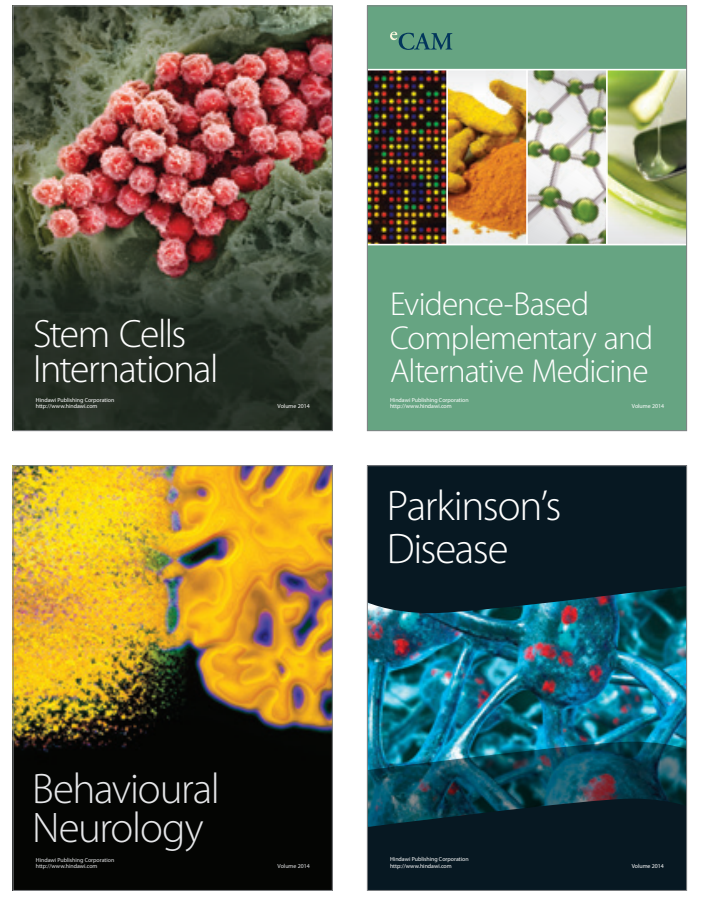
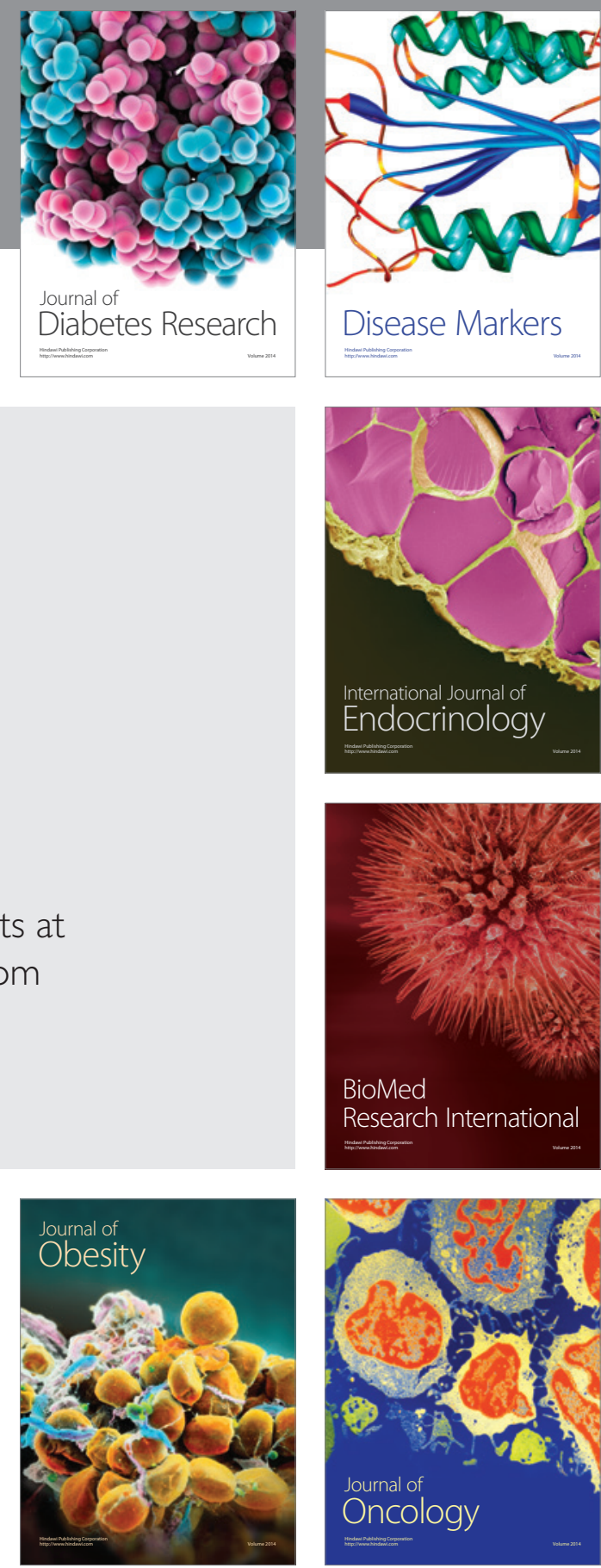

Disease Markers
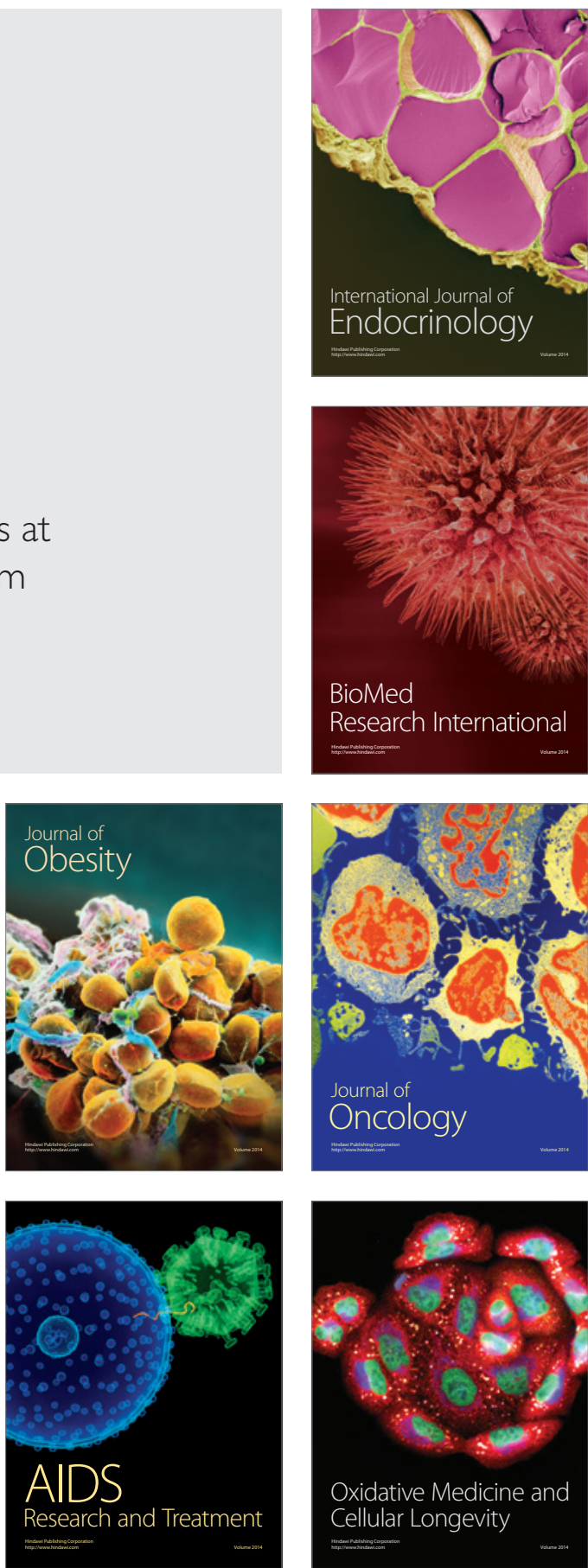